\title{
Assessment of heavy metals in livers of cattle and chicken by spectroscopic method
}

\author{
Parekhan Aljaff ${ }^{1}$, Banaz O.Rasheed ${ }^{2}$, Dler. M. Salh ${ }^{3}$ \\ ${ }^{\prime 2}$ Physics Department, School of Science, Faculty of Science and Educational Science, Sulaimani University, \\ Kurdistan Region, Iraq \\ ${ }^{3}$ Chemistry Department, School of Science, Faculty of Science and Educational Science, Sulaimani University, \\ Kurdistan Region, Iraq
}

Abstract: Liver samples of cow, chicken, and sheep were taken for metal analysis, the results are presented for the levels of chromium, copper, iron, magnesium, lead, zinc, selenium, cobalt, nickel, and cadmium using Inductively Coupled Plasma-Optical Emission Spectrometer (ICP-OES).The samples were taken from the local markets in Sulaimani city, Kurdistan region of Iraq. The concentration of the above metals in the studied samples were found not to be significant $(p<0.05)$. They are generally low, and within tolerance limit.

Keywords: Animal (Cow, Chicken and Sheep) livers, Heavy metals, Spectrometer, ICP-OES.

\section{Introduction}

All metals are toxic at certain levels of intake however, in contrast to elements such as arsenic, chromium, copper, selenium, and zinc that have useful biological functions, cadmium, lead and mercury play no useful role and their intake should be limited to avoid organ damage [1].Metal ions are essential for functional expressions of many proteins in living organisms, while excess leads to issue and organ damage. all organisms have developed similar mechanism for utilizing and storing metals as a result of the evolutionary process, and it is now recognized that there is a relation between the levels of certain trace elements in human tissue and the appearances of various diseases[2,3].

The purpose of this work is to provide information on trace elements concentration in livers of cow, chicken and sheep which have been brought from Iran and available in sulaimani city markets.

\section{Materials and method}

Liver samples were collected randomly from animals (Cows, sheep and chickens) which have been brought from Iran and available in sulaimani city markets. All tissue samples were stored at $-10^{\circ} \mathrm{C}$. The tissues were chopped, thoroughly mixed, then weigh out $3 \mathrm{gm}$ and subjected for analyses. The analysis done by two stages: mineralization (Ashing in $600^{\circ} \mathrm{C}$ for 3 to 4 hours), after that digest by $3 \mathrm{ml} \mathrm{HNO}_{3} \mathrm{~m}$ then filtered the supernatants, then complete the volume of the final solution $100 \mathrm{ml}$ in volumetric flask, and determination of metals using a Inductively Coupled Plasma-Optical Emission Spectrometer (ICP-OES) 2100 Perkin Elmer.

STATISTICAL ANALYSISES: Data collected were presented as mean and standard deviation and were subjected to one way analysis is of variance (ANOVA) $(\mathrm{P}<0.05)$ to assess whether heavy metals varied significantly between animals. all statistical calculations were performed with (open office program)for windows.

\section{Results and discussion}

The concentrations of heavy metals in the livers of cow, chicken and sheep are presented in table 1.

Table( 1):concentration of heavy metals in the livers of cow, chicken, and sheep

\begin{tabular}{|c|c|c|c|}
\hline elements & $\begin{array}{c}\text { Concentration in } \\
\text { Cow }(\mu \mathrm{g} / \mathrm{g})\end{array}$ & $\begin{array}{c}\text { Concentration in } \\
\text { Chicken }(\boldsymbol{\mu g} / \mathrm{g})\end{array}$ & $\begin{array}{c}\text { Concentration in } \\
\text { sheep }(\boldsymbol{\mu g} / \mathrm{g})\end{array}$ \\
\hline $\mathrm{Cr}$ & $\mathbf{0 . 0 4 2 1 1}$ & $\mathbf{0 . 0 8 6 9 3}$ & $\mathbf{0 . 0 3 6 6 5}$ \\
\hline $\mathrm{Cu}$ & $\mathbf{0 . 4 2 0 6}$ & $\mathbf{0 . 1 5 8 3}$ & $\mathbf{0 . 4 0 2 5}$ \\
\hline Fe & $\mathbf{2 . 7 9 9}$ & $\mathbf{6 . 4 8 2}$ & $\mathbf{3 . 3 2 5}$ \\
\hline $\mathrm{Mn}$ & $\mathbf{0 . 1 0 5 6}$ & $\mathbf{0 . 0 9 0 7 1}$ & $\mathbf{0 . 0 8 0 8}$ \\
\hline Pb & $\mathbf{0 . 0 7 5}$ & $\mathbf{1 . 3 4 2}$ & $\mathbf{0 . 0 0 8 8 0 4}$ \\
\hline Zn & $\mathbf{6 . 4 8 9}$ & $\mathbf{0 . 0 1 7 4 2}$ & $\mathbf{4 . 9 3 7}$ \\
\hline $\mathrm{Se}$ & $\mathbf{0 . 0 8 0 7 7}$ & $\mathbf{0 . 0 0 5 9 1 9}$ & $\mathbf{0 . 0 7 2 4 7}$ \\
\hline $\mathrm{Co}$ & $\mathbf{0 . 0 3 4 5 3}$ & $\mathbf{0 . 0 9 0 4}$ & $\mathbf{0 . 0 2 2 4 1}$ \\
\hline $\mathrm{Ni}$ & $\mathbf{0 . 2 4 5 9}$ & $\mathbf{0 . 0 0 5 0 9}$ & $\mathbf{0 . 1 2 1 3}$ \\
\hline $\mathrm{Cd}$ & $\mathbf{0 . 0 0 6 0 5}$ & & $\mathbf{0 . 1 3 0 1}$ \\
\hline
\end{tabular}

Nd (not determined) 


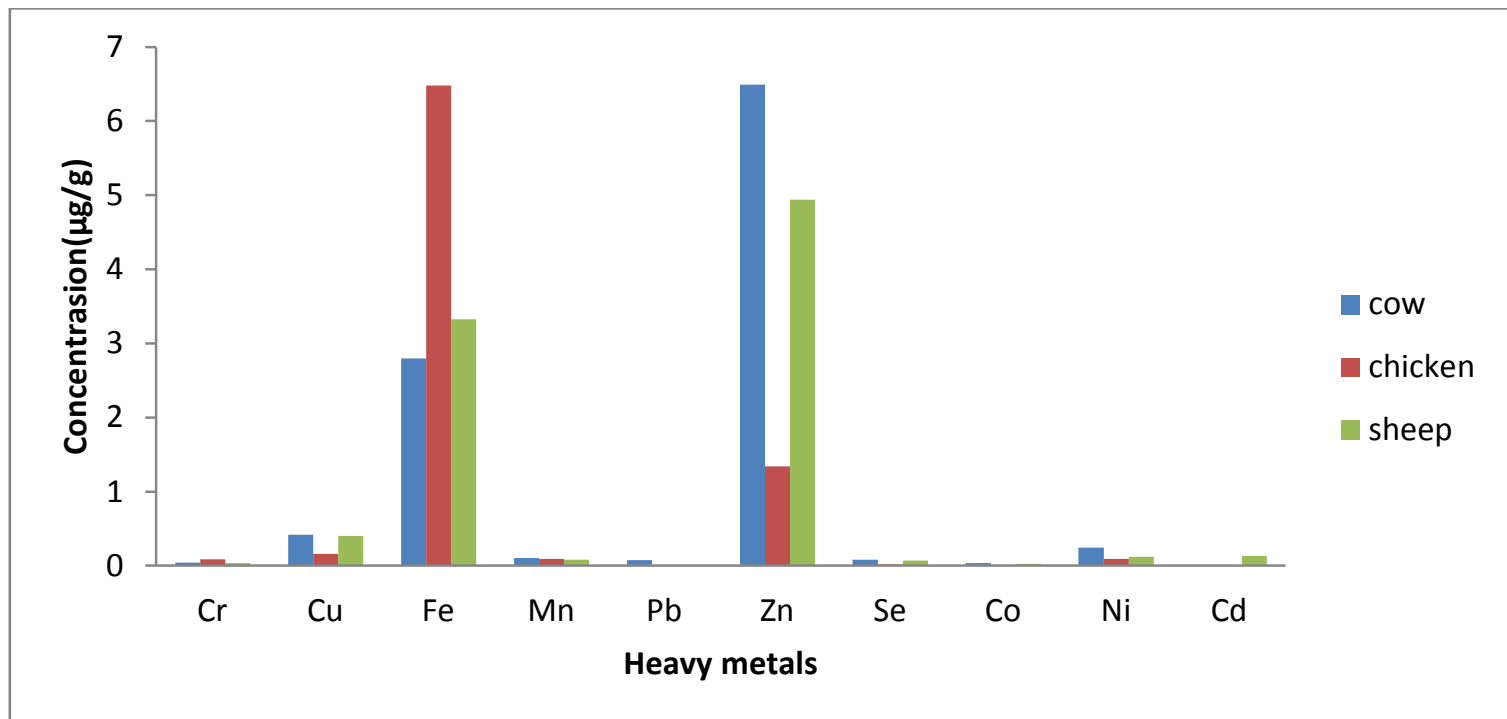

Fig.1 mean values of lead, cadmium and mercury in liver of cow , chicken, and sheep from local city of Sulaimani

Iron $(\mathrm{Fe})$ and Zinc ( $\mathrm{Zn}$ ) have the highest concentration in the three samples as compared to the other elements. The concentration of iron (Fe) in the liver of cow ,chicken and sheep showed significant variation the results indicate that liver of chicken contained the highest concentration of $(6.482 \mu \mathrm{g} / \mathrm{g})$,followed by sheep's liver $(3.325 \mu \mathrm{g} / \mathrm{g})$, while cows liver showed $(2.799 \mu \mathrm{g} / \mathrm{g})$. The toxicity of iron is governed by absorption. The more you take in the more you are at risk. The iron is absorbed in the ferrous state by cells of the intestinal mucous. Gastric and intestinal secretions can reduce ferric ions (the unusable form of the iron) to the ferrous (absorbable) state. Ferritin is a unique iron storage protein containing 24 storage proteins. When excess dietary iron is absorbed, the body produces more ferritin. Ferritin is greatly abundant in the heart and liver, therefore there is a large amount in these organs, and iron rushes to these organs for storage [4]. The body can only produce so much of these proteins; however, so excess iron builds up in these organs and causes tissue destruction. Zinc $(\mathrm{Zn})$ concentration was found to be highest in the liver of cow with $(6.489 \mu \mathrm{g} / \mathrm{g})$ while the least value was in the liver of chicken (1.342ppm)(fig.1), Same level value had gone for chicken in [5]. Zinc is an essential element in human diet too little Zinc is harmful to human health [6]The concentration of zinc in all the studied samples were less than the permissible limit 10-50 $\mathrm{ppm}(\mu \mathrm{g} / \mathrm{g})$ set by $[7,8,9]$.

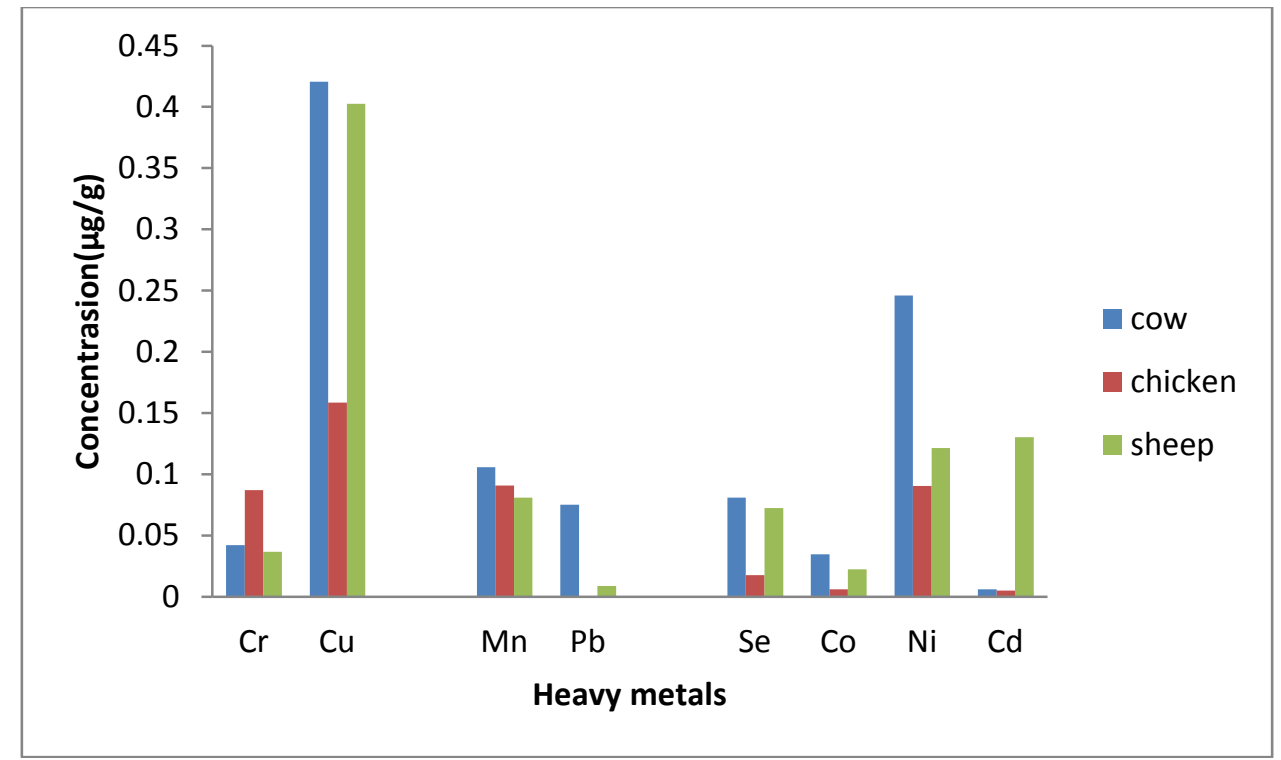

Fig.2:concentrations of ( $\mathrm{Cr}, \mathrm{Cu}, \mathrm{Mn}, \mathrm{Pb}, \mathrm{Se}, \mathrm{Co}, \mathrm{Ni}$,and $\mathrm{Cd})$ in liver of cow, chicken and sheep . 
Fig 2 shows zoom in graph of the other metals concentration the concentration of chromium $(\mathrm{Cr})$ in all liver samples were less than permissible limit $(0.1 \mu \mathrm{g} / \mathrm{g})$. Cr is an essential element helping the body to use sugar, protein and fat at the same time it is carcinogenic for organisms, excessive amounts of $\mathrm{Cr}$ may cause adverse health effects [4].

The highest copper concentration was found in the liver of cow $(0.4206 \mu \mathrm{g} / \mathrm{g})$ and the least value was observed in chicken $(0.1583 \mu \mathrm{g} / \mathrm{g})$.the copper concentration in the liver of the samples was below the permissible limit of 200ppm[5].

Manganese is an essential trace element that is normally present in all mammalian tissues in concentrations ranging from 0.3 to $2.9 \mu \mathrm{g} / \mathrm{g}$. Manganese is required for the normal development and function of the central nerves system. It was observed that the range of $\mathrm{Mn}$ in three samples were below the permission level.

The concentration of Lead ( $\mathrm{pb}$ ) in the liver of the samples were lower than the permissible limit of 1ppm [9], it shows that the sample of animals were not contaminated by the breeding area like industrial and chemical factories which will result in the air, water, and feed pollution.

Selenium Se concentrations were under $(0.1 \mu \mathrm{g} / \mathrm{g})$, In humans and animals, selenium is an essential nutrient that plays a role in protecting tissues from oxidative damage as a component of glutathione peroxides. Although selenium is an essential nutrient, exposure to high levels via inhalation or ingestion may cause adverse health effects. Selenium appears to affect the ability of liver enzymes to activate some chemical mutagens Selenium accumulates in many organ systems in the body; in general, the highest concentrations are found in the liver and kidney [10].

The highest concentration of cobalt (Co) in the samples were low, Co is required in the form of cobaltcontaining vitamin B 12. Co is widely distributed in the animal organ in relatively high concentration in liver, kidney, bone, spleen, and other glandular tissues [5, 11].

The concentration of nickel $(\mathrm{Ni})$ in the liver of cow, chicken, and beef ranged between $(0.2459,0.0904$, and $0.1213 \mu \mathrm{g} / \mathrm{g}$ ) the highest $\mathrm{Ni}$ concentration was observed in the liver of cow. Humans may be exposed to nickel by breathing air, drinking water, eating food or smoking cigarettes. Skin contact with nickel-contaminated soil or water may also result in nickel exposure. In small quantities nickel is essential, but when the uptake is too high it can be a danger to human health [12].

The permissible limit for cadmium in liver has been reported as $(0.5 \mathrm{ppm})$ set by [13]. In the present study the concentrations of $\mathrm{Cd}$ for all the samples were below the tolerance limit as shown in the table. Cadmium is not regarded as essential to human life. Much of the cadmium which enters the body by ingestion comes from terrestrial foods. This is to say, from plants grown in soil or meat from animals which have ingested plants grown in soil. Thus, directly or indirectly, it is the cadmium present in the soil and the transfer of this cadmium to food plants together with the cadmium deposited out of the atmosphere on edible plant parts which establishes the vast majority of human cadmium intake, Some have estimated that $98 \%$ of the ingested cadmium comes from terrestrial foods, while only $1 \%$ comes from aquatic foods such as fish and shellfish, and $1 \%$ arises from cadmium in drinking water [9]. The mean concentration of Cadmium in liver of younger animals $<2$ years being much lower than the level of older animal $>2$ years [14].cadmium levels in the liver of chicken available in the market of Basrah city were in the tolerance limits[8].

\section{Conclusion:}

From the results of this paper, the concentration of all metals in the livers of cow, chicken, and sheep were found not to be statistically significant $(\mathrm{p}<0.05)$ and the levels of all the studied metals were within the tolerance limit.

\section{Reference}

[1]. H.L.Kramer,J.W..Steiner, P.J. Vallely. Trace element concentrations in the liver,kidney, and muscle of Queen land cattle. Bulletin of environmental contamination and toxicology Vol.30,588-589(1983)Springer.

[2]. K.Geraki,\&M.J. Farquharson,"An X-ray fluorescence for measuring trace element concentration in breast tissue." radiation physics and chemistry.61:603-605(2001).

[3]. M.J.Farquharson, K.Geraki, G.Flakenberg,R,Leek,\&A.Harris,"'the localization and micro maping of copper and other trace elements in breast tumours using a synchrotron micro-XRF system."Applied Radiation and Isotopes.65:183-188(2007)

[4]. Iron toxicity department of animal science,college of agriculture and life science .Cronel university received from: www.ansci.cornell.edu/plants/toxicagents/iron.html

[5]. J.C. Akan, 1F.I. Abdulrahman, 2O.A. Sodipo and 1Y.A. Chiroma. Distribution of Heavy Metals in the Liver, Kidney and Meat of Beef, Mutton,Caprine and Chicken from Kasuwan Shanu Market in Maiduguri Metropolis, Borno State, Nigeria. Applied Sciences, Engineering and Technology 2(8): 743-748, 2010

[6]. ATSDR, 2004. Agency for Toxic Substances and Disease Registry, Division of Toxicology, Clifton Road, NE, Atlanta, GA. Retrieved from: http://www.atsdr.cdc.gov/toxprofiles/.

[7]. $\quad$ surtipanti,S;Suwirma S;Yamiarti and Yune Mellawati.(1995).Determination of heavy metals in meet ,intestine,liver,eggs, andchicken using neutron activation analysise and atomic absorption spectroscopy.J Atom Indonesia.vol.21 no.83-93.

[8]. Reem Th. Hussain, Manal Kh. Ebraheem, Hanady M. Moker. 
[9]. ASSESSMENT OF HEAVY METALS $(C d, P b A N D Z n)$ CONTENTS IN LIVERS OF CHICKEN AVAILABLE IN THE LOCAL MARKETS OF BASRAH CITY, IRAQ.Bas.J.Vet.Res.Vol.11,No.1,2012.

[10]. ANZFA (Australia New Zealand Food Authority), 2001.Wellington NZ 6036 May, 2001. Retrieved from: URL:http://www.anzfa.gov.au.

[11]. ASTDR Agency for toxic substancesand desises registry2013 retrieved from: www.atsdr.cdc. gov/PHS/PHS. asp?id=243\&tid=44.

[12]. ASTDR 2004. Toxicological profile for cobalt. Atlanta, GA: US Department of Health and Human Services, Public HealthService. Disclaimer. ...

[13]. www.atsdr.cdc.gov/ToxProfiles/tp.asp?id=373\&tid=64

[14]. david C.Dorman,Milani F.Struve,R.Arden James,Brein E.Macmanus ,Marianne W.Marshall,and Brian A.Wong. Influence of dietary manganese on the pharmacokinetics of inhaled manganese sulfate in male CD Rats. toxicological science 60,242251(2001)

[15]. Van Assche, F. J., (1998) "A Stepwise Model to Quantify the Relative Contribution of Different Environmental Sources to Human Cadmium Exposure," Paper to be presented at NiCad '98, Prague, Czech Republic, September 21-22, 1998.

[16]. A. Zasadowski, D. Barski, K. Markiewicz1, Z. Zasadowski2, A. Spodniewska, A. Terlecka. Levels of Cadmium Contamination of Domestic Animals (Cattle) in the Region of Warmia and Masuria. Polish Journal of Environmental Studies Vol. 8, No. 6 (1999), $443-446$ 